\title{
Cascade reactions for syntheses of heterocycles
}

\author{
Masataka Ihara \\ Department of Organic Chemistry, Graduate School of Pharmaceutical Sciences, Tohoku \\ University, Aobayama, Sendai 980-8578, Japan \\ E-mail: mihara@mail.pharm.tohoku.ac.jp
}

\begin{abstract}
Cascade reactions are useful method for the construction of polycyclic skeletons, which are important cores for biological activities. A variety of cascade reactions, carried out under multiple reaction conditions, such as pericyclic, polar, radical, and transition metal catalyzed reaction conditions, have been investigated. Novel methodologies, developed by us, and their applications are discussed.
\end{abstract}

Keywords: Cascade reaction, polar reaction, radical reaction, transition metal catalyzed reaction, polycyclic compounds, biologically active compounds

\section{Contents}

Introduction

1. Cascade reaction under transition metal catalyzed conditions

2. Cascade reaction under radical conditions

3. Cascade reaction under polar conditions

3.1 Double Michael reaction

3.2 Aza double Michael reaction

3.3 Michael-aldol reaction

\section{Introduction}

When various functional groups exist on polycyclic skeleton, the three dimensional relationship of functional groups would be restricted and a specific biological activity would be expected due to the rigid conformation (Figure 1). Therefore, the development of efficient method for the construction of polycyclic ring systems would be highly desired particularly in the field of medicinal chemistry. Cascade reactions ${ }^{1-6}$ forming a number of bonds by one operation are 
useful for the creation of polycyclic compounds. Many stereogenic centers would be created at the same time. Reduction of reaction steps leads to saving reagents, energy and reduction of wastes. Therefore, cascade reaction is important from the economical point view and from the green chemistry. In this context, we have been studying cascade reactions carrying out under various reaction conditions, such as pericyclic, polar reaction, radical reaction, and transition metal catalyzed conditions. Recent progress relating to heterocycles would be accounted.

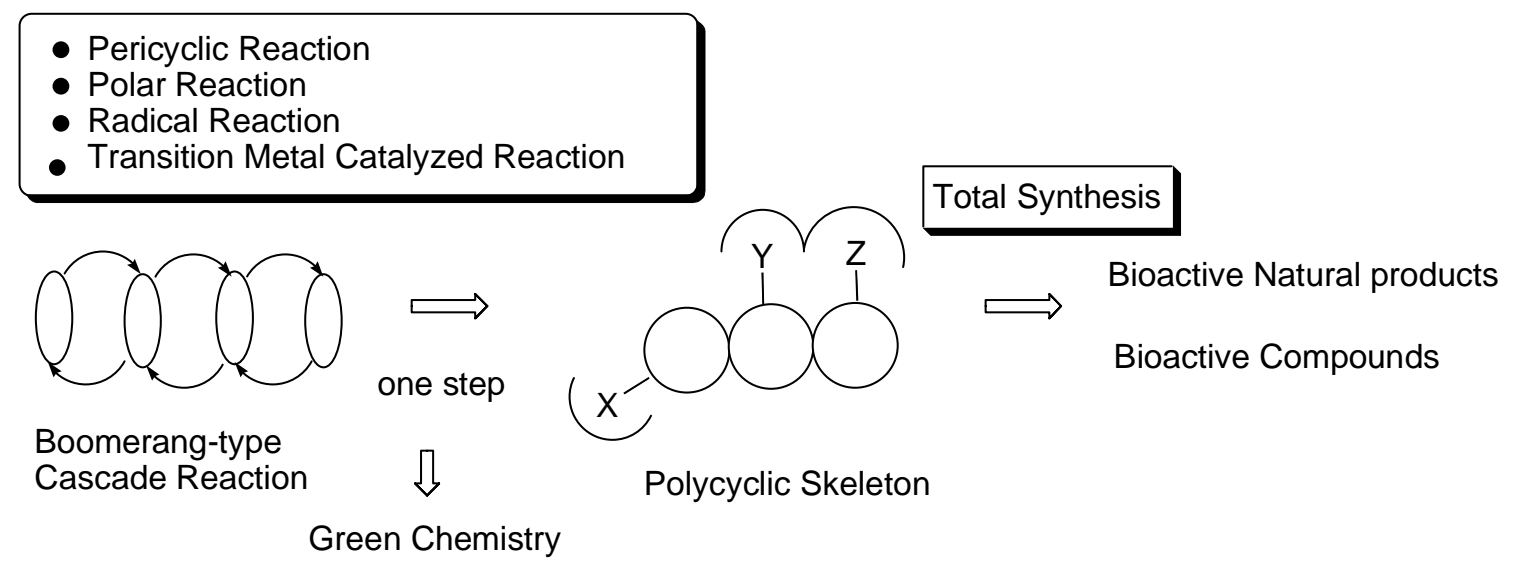

\section{Figure 1}

\section{Cascade reaction under transition metal catalyzed conditions}

Several cascade reactions of cyclobutanols forming cyclpentane derivatives have been performed by palladium or ruthenium catalyst ${ }^{7}$ and a novel cascade reaction forming cyclic carbonates has been also devised (Scheme 1). When the propargylic carbonate 1 was treated with $p$ methoxyphenol in the presence of catalytic amount of zero valence of palladium catalyst under Ar atmosphere, the cyclic carbonate $\mathbf{2}$ was obtained together with the dihydrofuran $\mathbf{3}$ and the epoxide 4. The reaction, carried out under $\mathrm{CO}_{2}$ atmosphere, gave the cyclic carbonate 2 in a quantitative yield. On the other hand, bubbling with $\mathrm{Ar}$ during the reaction to remove $\mathrm{CO}_{2}$ resulted in the increased formation of the dihydrofuran 3 and the epoxide $4 .^{8}$ 


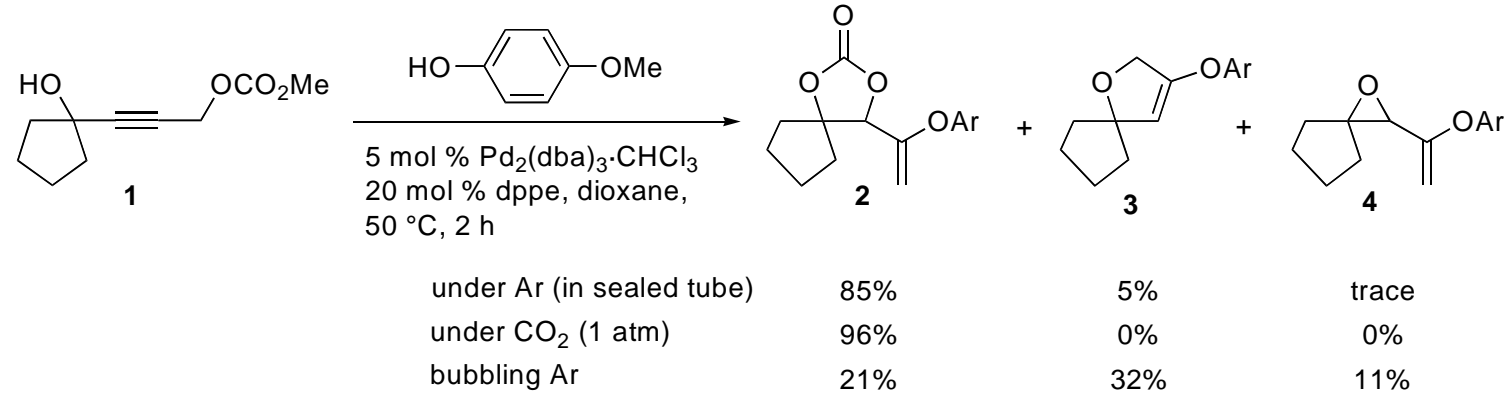

\section{Scheme 1}

On the basis of the above observations, a possible mechanism for the transformation is considered as shown in Scheme 2. Reaction of the propalgylic carbonate 5 with palldium catalyst would afford $\mathrm{CO}_{2}$ and the allenylpalladium $\mathbf{6}$, which equilibriums with the $\pi$-propargylpalladium 7. Attack of the phenol to $\mathbf{7}$ yields the $\pi$-allylpalladium complex $\mathbf{8}$, which could trap $\mathrm{CO}_{2}$ to provide the cyclic carbonate $\mathbf{1 0}$ via $\mathbf{9}$ and zero valence palladium. The dihydrofuran 3 and the epoxide 4 must be directly formed from the $\pi$-allylpalladium complex. ${ }^{8}$

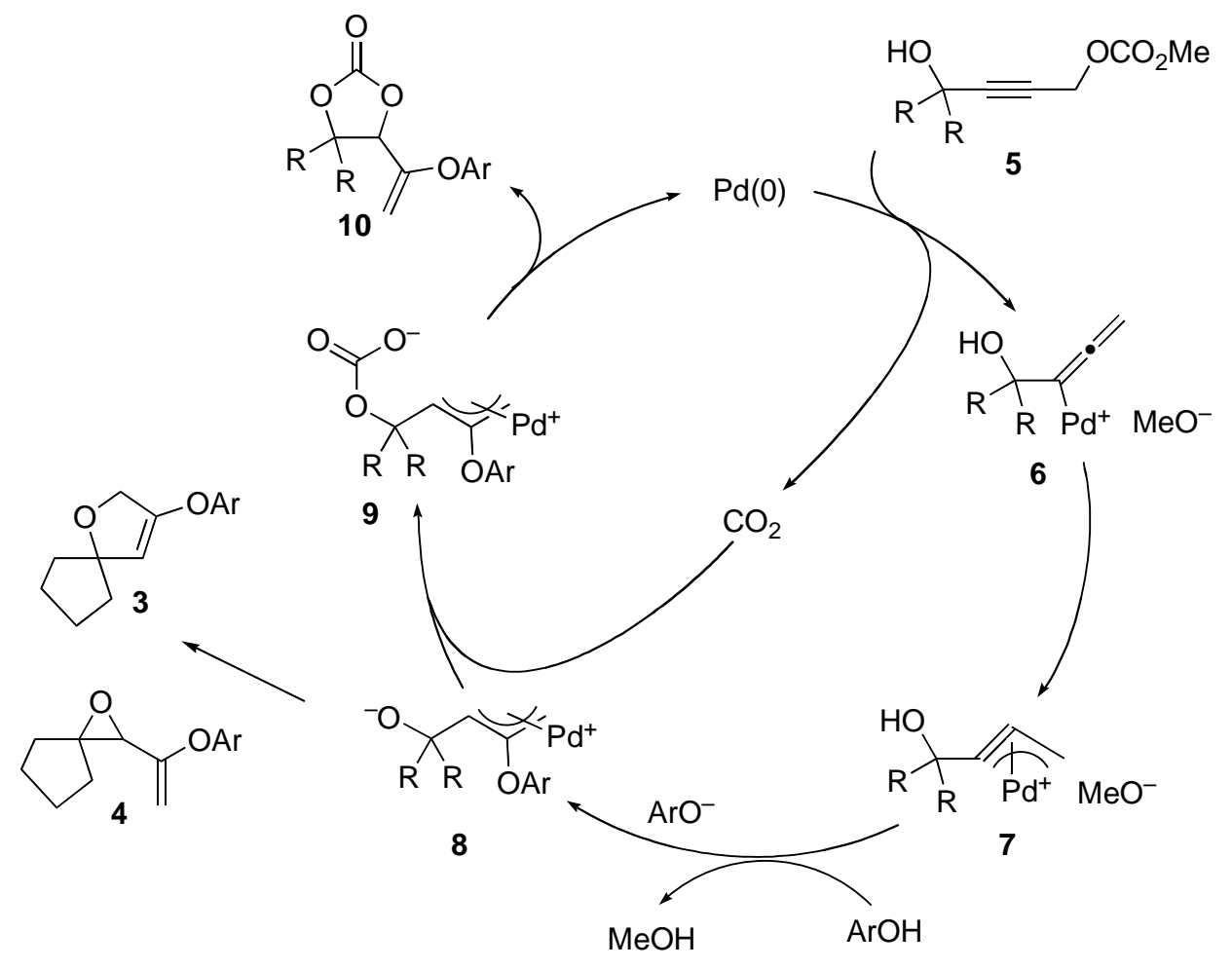

\section{Scheme 2}

Various cyclic carbonates were prepared in good yields by this procedure. It was noteworthy that when the phenyl carbonate $\mathbf{1 1}$ was used as a substrate, the cyclic carbonate $\mathbf{1 2}$ 
was quantitatively obtained in the absence of the phenol (Scheme 3). The reaction must be performed via splitting into three components followed by their recombination without any loss of atoms. ${ }^{8}$

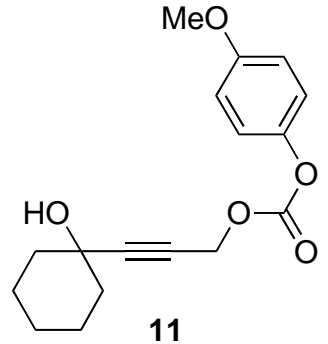

11
$5 \mathrm{~mol} \% \mathrm{Pd}_{2}(\mathrm{dba})_{3} \cdot \mathrm{CHCl}_{3}$

$20 \mathrm{~mol} \%$ dppe

dioxane, rt, $4 \mathrm{~h}$

$(99 \%)$

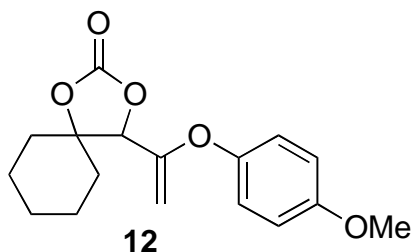

12

\section{Scheme 3}

Catalytic asymmetric synthesis was easily applied to the above $\mathrm{CO}_{2}$ fixation reaction. ${ }^{9}$ Thus, a highly optically active product 14 was produced from the symmetrical compound 13 in the presence of a catalytic amount of a chiral ligand (Scheme 4). The preferred formation of one enantiomer could be explained by the favorable transition state $\mathbf{A}$ over $\mathbf{B}$. The chirality transfer reaction was also studied. ${ }^{10}$
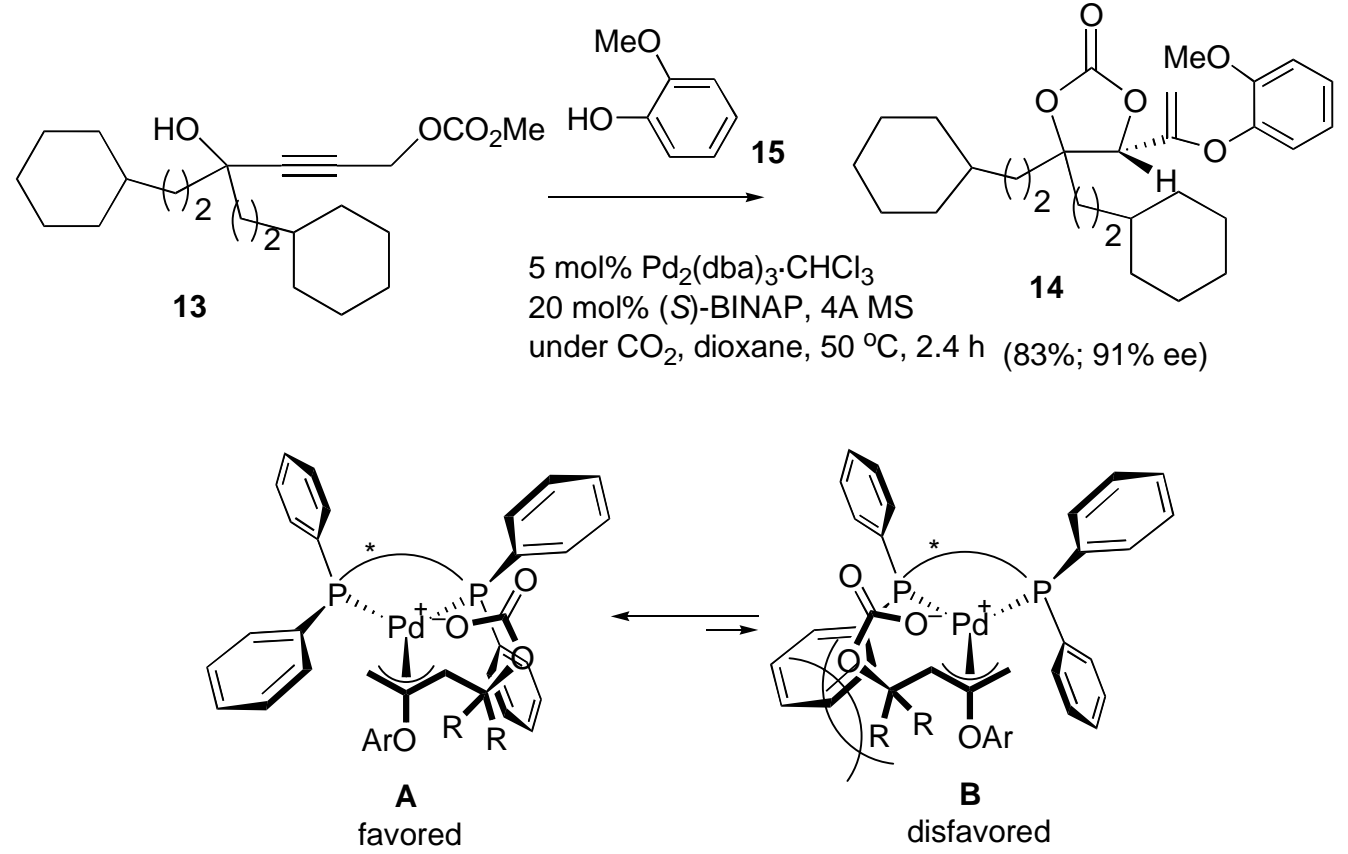

\section{Scheme 4}




\section{Cascade reaction under radical conditions}

In addition to our cascade reactions under radical conditions, ${ }^{11}$ a novel strategy for the synthesis of heterocyclic spiro compounds has been worked out. Treatment of the piperidin-2-one derivative 16 with $\mathrm{Bu}_{3} \mathrm{SnH}$ in the presence of $\mathrm{AIBN}$ in hot benzene caused the radical translocation followed by radical cyclization to give the aza-spiro compounds $\mathbf{1 7}$ and 18. The diasterelselectivity of the one product $\mathbf{1 7}$ was improved, when tert.-butyl ester was used (Scheme 5). The same transformation was also carried out under electroreductive reaction conditions, the environmentally friendly methodology. The preferred formation of $\mathbf{1 7}$ could be explained by the transition states of the radical intermediates. The major product $\mathbf{1 7}$ was converted into the diol 19, a possible synthetic intermediate of pinnaic acid and halichlorine. ${ }^{12}$

\section{Cascade reaction under polar conditions}

\subsection{Double Michael reaction}

Bicyclo[2.2.2] octane skeleton is a framework of several natural products. We encountered a difficulty for stereoselective synthesis of the corresponding polycyclic systems using the intramolecular Diels-Alder reaction. ${ }^{13}$ The problem was solved by the intramolecular double Michael reaction, carried out by the treatment with $\operatorname{LiN}(\mathrm{TMS})_{2}{ }^{14}$

As a typical example of the application of this methodology, a synthetic plan of atisine is shown in Scheme $6 .{ }^{15}$ Since synthesis of racemic atisine had been carried out by several workers, the asymmetric synthesis was designed. The synthetic intermediate 20 could be stereoselectivly obtained by the intramolecular double Michael reaction of the enone 21. We envisaged that the substrate $\mathbf{2 1}$ of the key reaction could be prepared as an optically active form from the symmetrical compound 22, derived from 23.

The diol 25, obtained via 24 from 23, was subjected to lipase-catalyzed transesterification

in neat vinyl acetate to afford the acetate 26 in an optically pure form (Scheme 7). ${ }^{16}$ The absolute configuration was determined by X-ray analysis of the corresponding camphorsulfonyl derivative. 
<smiles>[R]OC(=O)/C=C/CCCC1CCCC(=O)N1Cc1ccccc1Br</smiles>

16<smiles>[R][R]C(=O)C[C@@H]1CCC[C@]12CCCC(=O)N2Cc1ccccc1</smiles>

17
$88 \%(7: 2)$

$78 \%(10: 1))$

$62 \%(10: 1))$

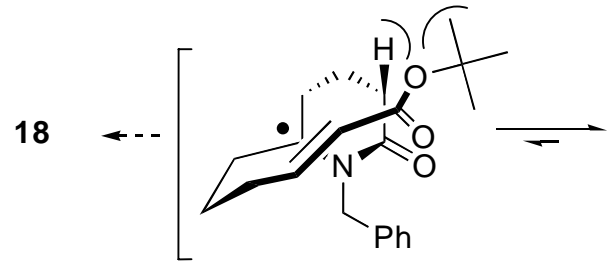

unfavorable TS

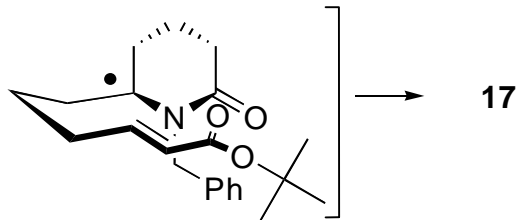

favorable $\underline{\text { TS }}$

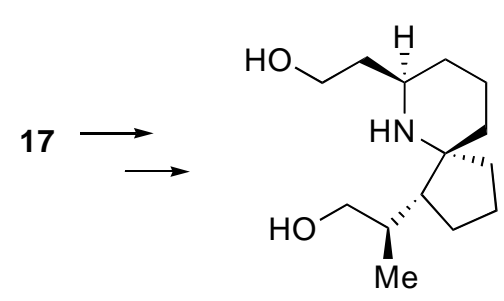

19<smiles>C/C(=C\C[C@@H]1CCC[C@]2(CCC[C@H]2[C@H](C)/C=C/[C@@H](O)/C=C(\Cl)CCO)N1)C(=O)O</smiles>

pinnaic acid

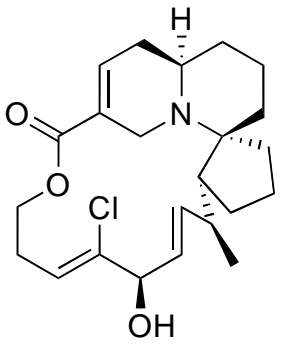

halichlorine

\section{Scheme 5}

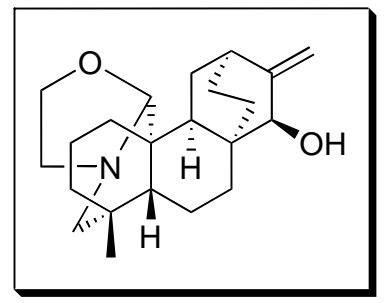

atisine<smiles>C=C</smiles><smiles>COC(=O)C1CCCC(C(C)=O)C1=O</smiles>

23

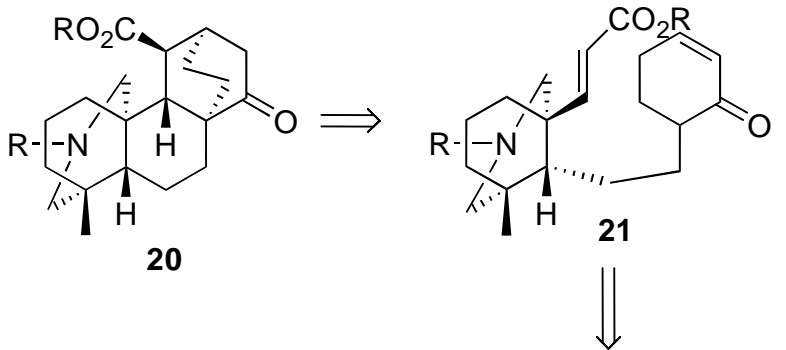<smiles>C=C</smiles><smiles>[R]CN1CCC2(C(=O)OC)CC1(C(=O)OC)CC2C(=O)OC</smiles>

22

\section{Scheme 6}




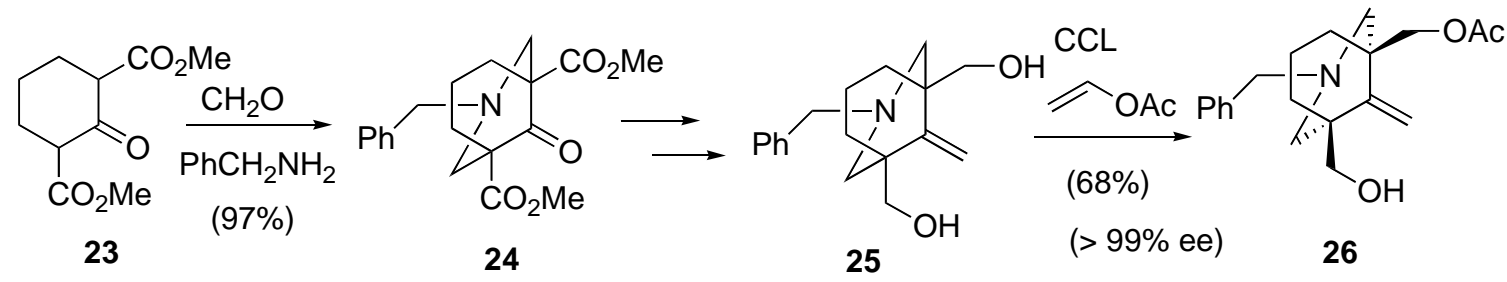

\section{Scheme 7}

The chiral acetate 26 was transformed to the enone 27, which was treated with $\mathrm{LiN}(\mathrm{TMS})_{2}$ to provide the desired penta cyclic compound $\mathbf{2 8}$ as a single diastereoisomer. The product $\mathbf{2 8}$ was then converted into 29, which had been correlated with atisine. Thus, asymmetric synthesis of atisine has been accomplished in a highly stereoselective manner (Scheme 8). ${ }^{15}$

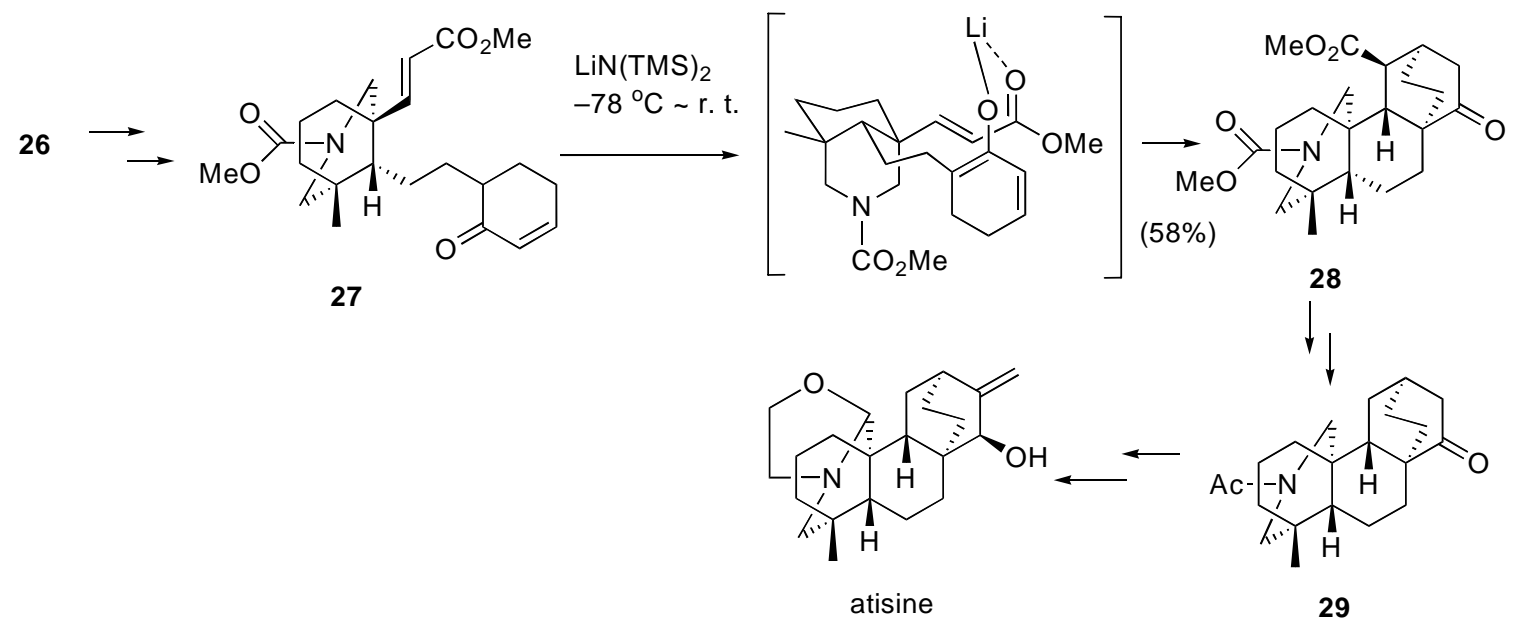

\section{Scheme 8}

\subsection{Aza double Michael reaction}

The success of the above double Michael reaction promoted us to investigate extensions of the strategy for the synthesis of heterocyclic compounds. We planned the construction of piperidin2-ones 30 by reactions of $\alpha, \beta$-unsaturated amides with $\alpha, \beta$-unsaturated carbonyl groups as shown in Scheme 9. 


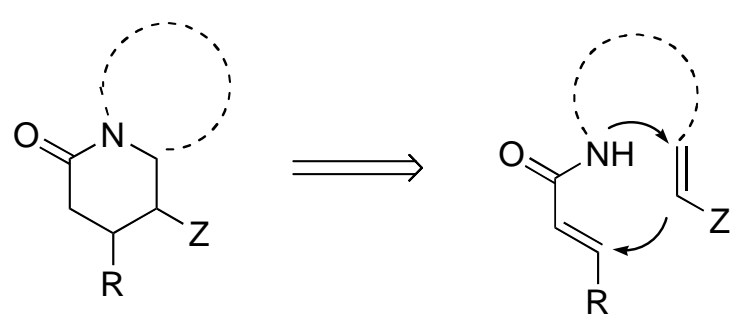

30

\section{Scheme 9}

The desired intramolecular cascade reaction was successfully performed under several reaction conditions, such as heating with a mixture of $\mathrm{TMSCl}, \mathrm{Et}_{3} \mathrm{~N}$ and $\mathrm{ZnCl}_{2},{ }^{17}$ treatment with TBSOTf in the presence of $\mathrm{Et}_{3} \mathrm{~N},{ }^{18}$ treatment with TMSI in the presence of (TMS $)_{2} \mathrm{NH},{ }^{19}$ and treatment with $\mathrm{Bu}_{2} \mathrm{BOTf}$ in the presence of (TMS $)_{2} \mathrm{NH}^{19}$

For example, treatment of $\mathbf{3 1}$ with TBSOTf in the presence of $\mathrm{Et}_{3} \mathrm{~N}$ at room temperature gave two diastereoisomers, 32 and 33. When the $N$-tosylate was used as a substrate, the diastereoselective formation of $\mathbf{3 2}$ was improved (Scheme 10). ${ }^{18 \mathrm{~b}}$ Formation of $\mathbf{3 2}$ having syn hydrogens at the 1 and $12 \mathrm{~b}$ positions would support a stepwise mechanism for the transformation. It was observed that the rate of reaction was enhanced by the use of dichloroethane in stead of dichloromethane as a solvent.

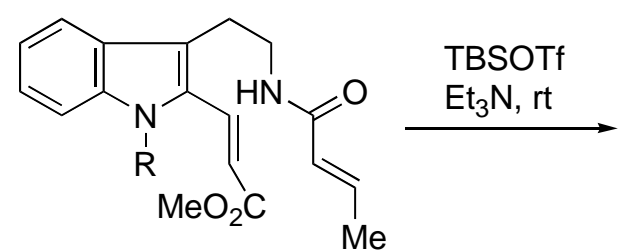

31

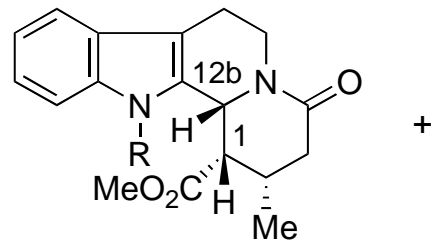

32

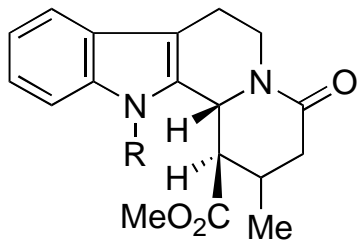

33

$$
\begin{array}{lllll}
\mathrm{R}=\mathrm{H} & (60 \%) & 60 & : & 40 \\
\mathrm{R}=\mathrm{Ts} & (94 \%) & 83 & : & 17
\end{array}
$$

\section{Scheme 10}

The method was applied to the synthesis of tacamonine, isolated from Tabernaemontana eglandulosa. The substrate 34 of the key reaction was prepared in two steps from the dihydro- $\beta$ carboline hydrochloride (Scheme 11). Treatment of 34 with TBSOTf and $\mathrm{Et}_{3} \mathrm{~N}$ in dichloroethane provided two diastereoisomers 35 and 36 . The product 35 was reduced with borane to give the amine 37, which had been transformed into tacamonine by Lounasmaa. ${ }^{20}$ Thus, a short synthesis of the racemate of tacamonine was accomplished. ${ }^{21}$ It is observed by using our synthetic sample that $\mathrm{IC}_{50}$ of $( \pm)$-tacamonine against $\mathrm{M} 2$ receptor is $0.9 \mu \mathrm{g} / \mathrm{ml}$. 
The naturally occurring enantiomer of tylophorine was synthesized by the diastereofacially controlled intramolecular aza double Michael reaction. Prior to our work, optically active tylophorine was synthesized starting with amino acids. ${ }^{22}$ So, the naturally occurring $(R)$ enantiomer had not been chemically prepared. We designed an asymmetric synthesis of tylophorine possessing the desired absolute configuration by the cascade reaction, whose stereochemistry would be controlled by a chiral auxiliary.

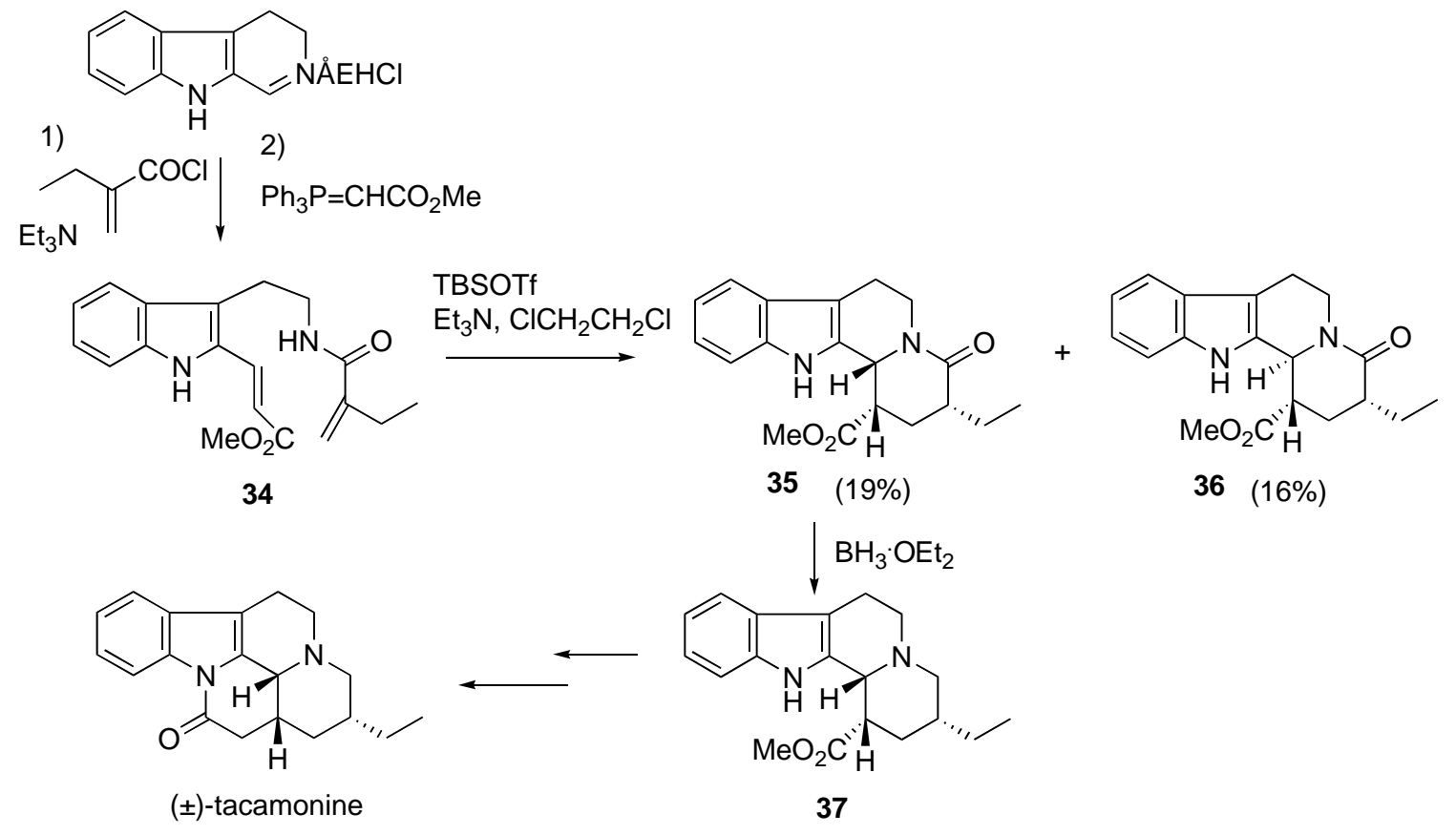

\section{Scheme 11}




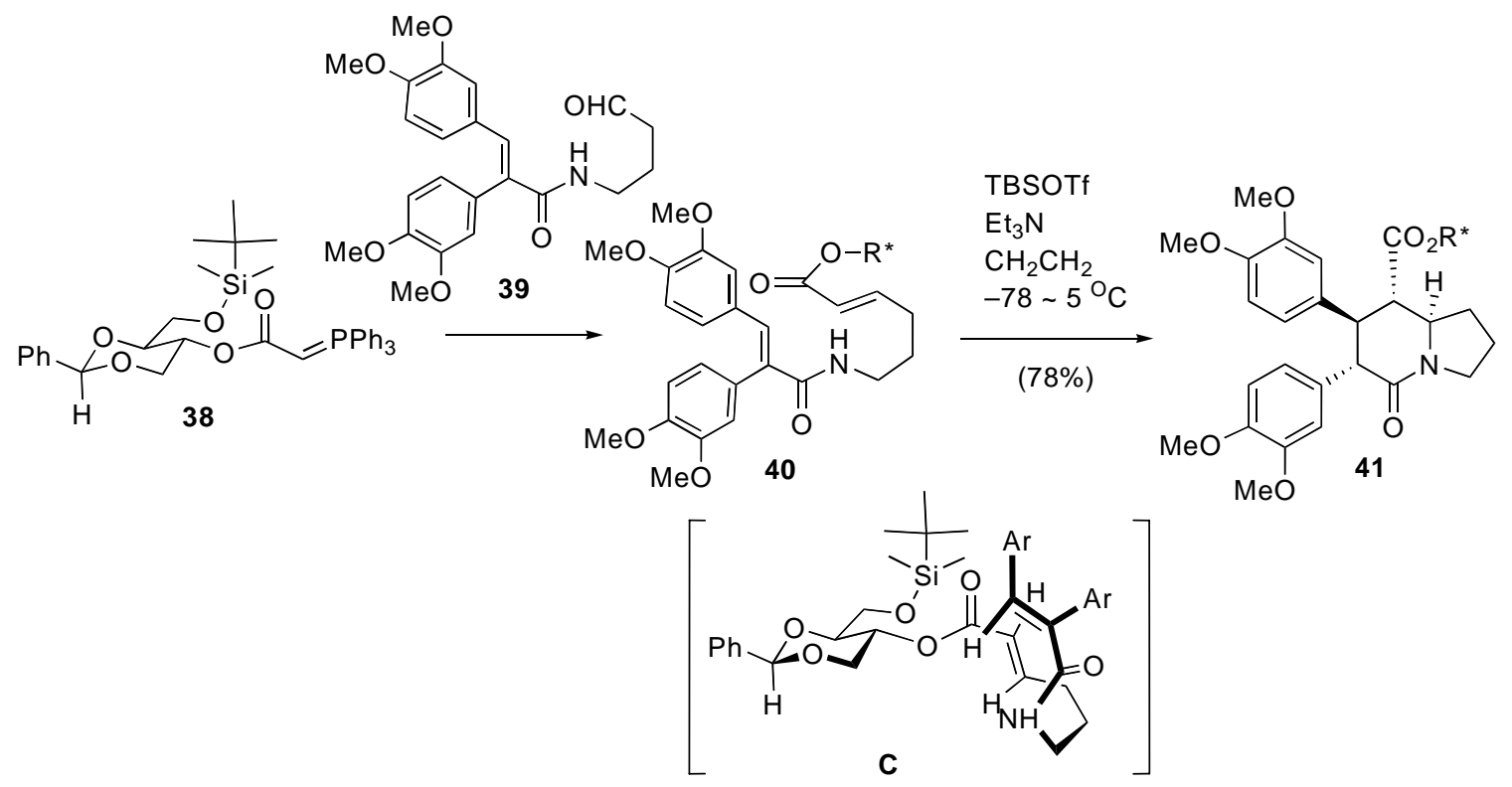

\section{Scheme 12}

A novel chiral auxiliary was prepared from glucose and converted to the phosphorane $\mathbf{3 8}$, which was reacted with the aldehyde 39 to afford the $\alpha, \beta$-unsaturated ester $\mathbf{4 0}$. Treatment of $\mathbf{4 0}$ with TBSOTf in the presence of $\mathrm{Et}_{3} \mathrm{~N}$ furnished the indolizidine $\mathbf{4 1}$ as a single diastereisomer.

The presence of Lewis acid such as TBSOTf would force the $\alpha, \beta$-unsaturated ester part as a s-trans form and the $\alpha, \beta$-unsaturated amide part would approach from the less hindered si-re face (Scheme 12). Thus, the desired compound having the $(R)$-configuration at the angular position could be preferentially formed via the transition state $\mathbf{C}$. The result was confirmed by the transformation of the product $\mathbf{4 1}$ into the natural product (Scheme 13). ${ }^{23}$

41

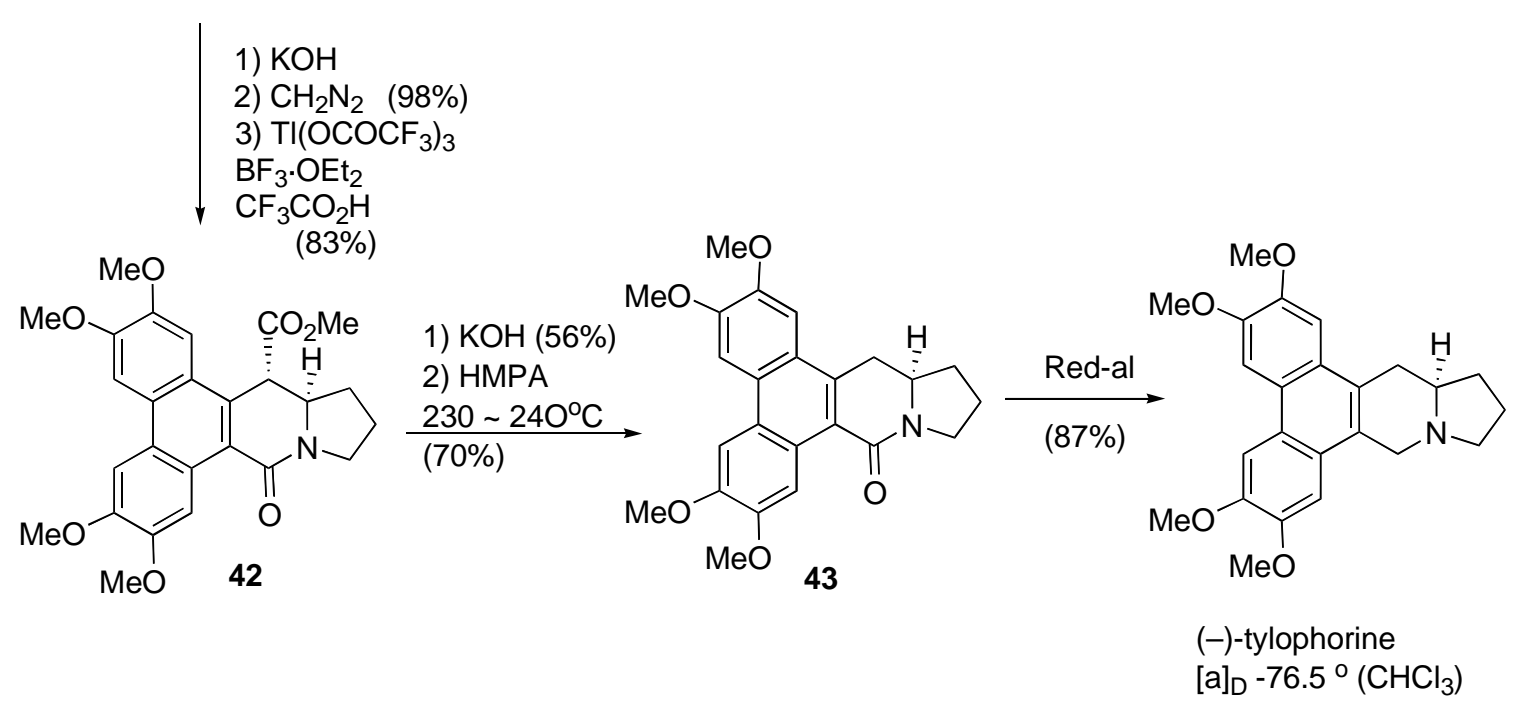

Scheme 13 
After conversion of $\mathbf{4 1}$ to the corresponding methyl ester, phenanthroindolizidine $\mathbf{4 2}$ was constructed by the oxidative aryl coupling. Removal of the ester function via the carboxylic acid, followed by reduction with red-al, produced (-)-tylophorine, whose first chiral synthesis was thus effectively achieved.<smiles>CCC(=O)c1cc2n(c(=O)c1C)CCc1cc3ccccc3nc1-2</smiles>

mappicine ketone

Recently, Greene and co-workers synthesized mappicine ketone having anti herpes virus activity by the application of this strategy. ${ }^{24}$

Although the stepwise mechanism was supported by the formation of the two diastereomers 32 and $\mathbf{3 5}$ from the $(E)-\alpha, \beta$-unsaturated ester 31, the solution of mechanism of the cascade reaction is an attractive problem. For this purpose, the structures of products, formed by the reaction of $\alpha, \beta$-unsaturated amide with the silylating agents, were studied, since two possibilities, the $N$-silyl amide 44 and $O$-silyl imidate (1-aza-2-siloxydiene) 45, are expected (Figure 2).<smiles>[R]C=CC(=O)N([R])[R]</smiles>

44<smiles>[R]C=CC(=N[R])O[Hg]</smiles>

45

\section{Figure 2}

Treatment of $\alpha, \beta$-unsaturated amides with TBSOTf and $\mathrm{Et}_{3} \mathrm{~N}$ did not afford pure products. But, pure compounds were obtained by treatment with $\mathrm{TBSCl}$ and $\mathrm{NaH}$. The structures of products 47 and 49, produced from 46 and 48, respectively, were determined as the 1-aza 2siloxydienes on the basis of ${ }^{15} \mathrm{~N}$ and ${ }^{29} \mathrm{Si}$ NMR as well as UV spectroscopies as shown in Scheme $14 .^{25}$ 


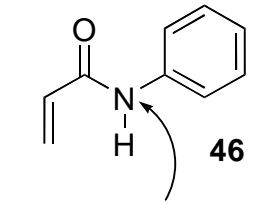

${ }^{15} \mathrm{~N}: 133.9\left(\mathrm{~d}, \mathrm{~J}_{\mathrm{N}-\mathrm{H}}=90.0 \mathrm{~Hz}\right)$

$$
\lambda_{\max }=268.5 \mathrm{~nm}
$$

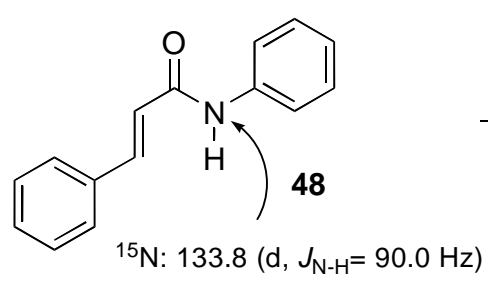

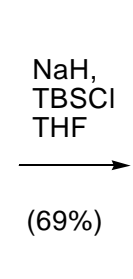

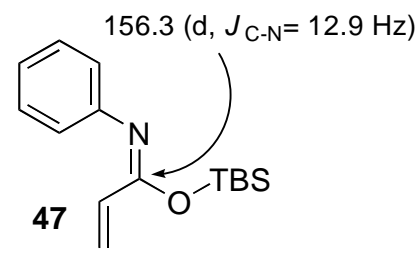

$$
\begin{aligned}
& { }^{15} \mathrm{~N}: 265.5(\mathrm{~s}) \\
& { }^{29} \mathrm{Si}: 23.5(\mathrm{~s}) \\
& \lambda_{\max }=297.0 \mathrm{~nm}(\mathrm{MeCN})
\end{aligned}
$$

$156.7\left(\mathrm{~d}, \mathrm{~J}_{\mathrm{C}-\mathrm{N}}=12.9 \mathrm{~Hz}\right)$

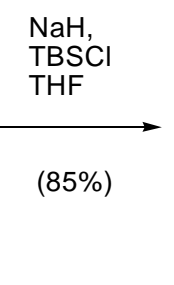

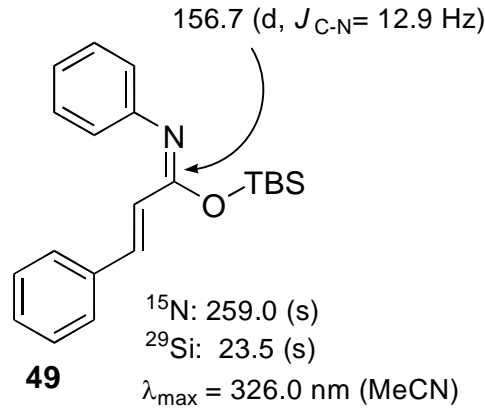

\section{Scheme 14}

The formed 1-aza-2-siloxydiene $\mathbf{5 0}$ was reacted with methyl acrylate in the presence of Lewis acids (Scheme 15). The desired piperidin-2-one derivative 51 was obtained by treatment with TBSOTf or $\mathrm{FeCl}_{3}$. Dimer 52, derived from 50, was obtained in a significant amount. The formation of the unsaturated amide 53 would indicate the stepwise mechanism. ${ }^{25}$

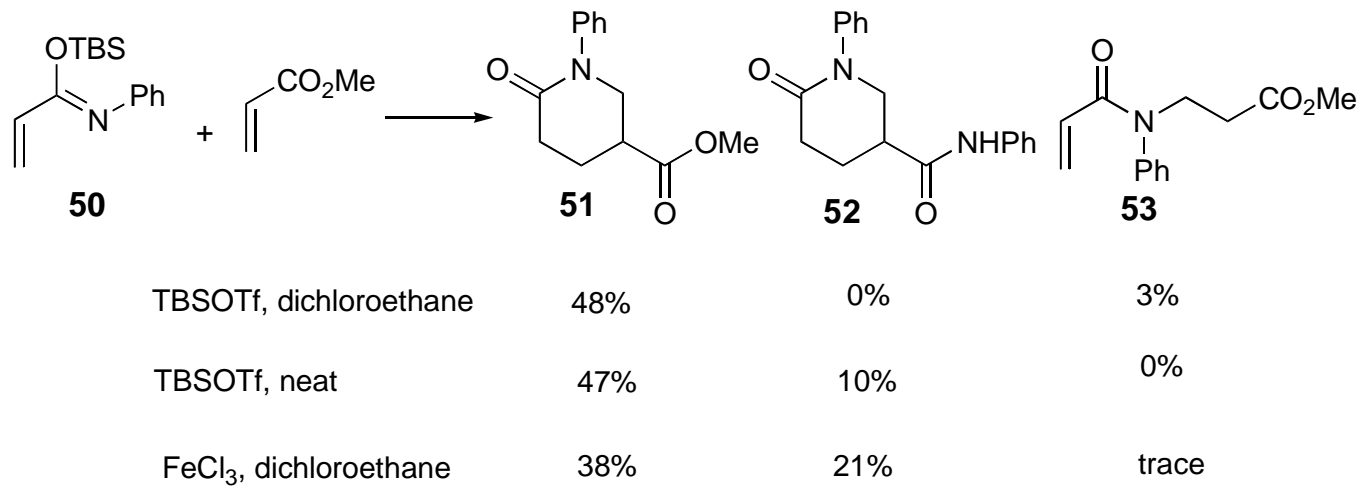

\section{Scheme 15}

We next investigated the intermolecular cascade reaction between $\alpha, \beta$-unsaturated amide and $\alpha, \beta$-unsaturated carbonyl compounds (Scheme 16). However, reaction of the acryloyl amide 54 with $\alpha, \beta$-unsaturated carbonyl compounds in the presence of TBSOTf and $\mathrm{Et}_{3} \mathrm{~N}$ resulted in the formation of the dimmer $\mathbf{5 6}$ of $\mathbf{5 4}$. No formation of the desired compound $\mathbf{5 5}$ was observed. 

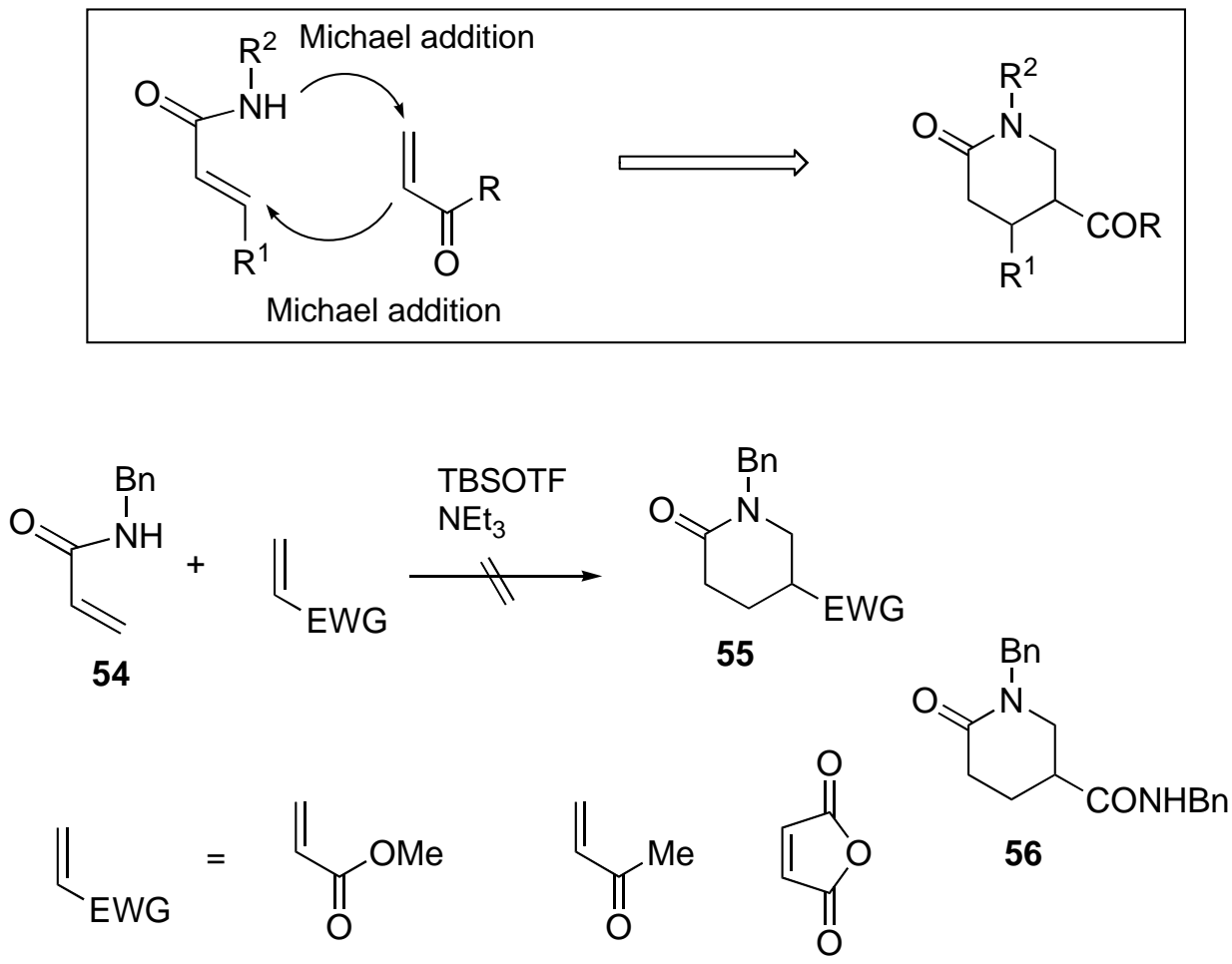

\section{Scheme 16}

It was suggested on the consideration of the high yield formation of the previous products 32 and 33 that the presence of a substituent at the $\beta$-position of the $\alpha, \beta$-unsaturated amide would be preferable for the cross process. The desired compound 58 was actually obtained from 57 . It was further established that the use of excess TBSOTf and the presence of a catalytic amount of $t$ - $\mathrm{BuOH}$ are required for the production of the desired compound in a good yields (Scheme 17). ${ }^{26}$

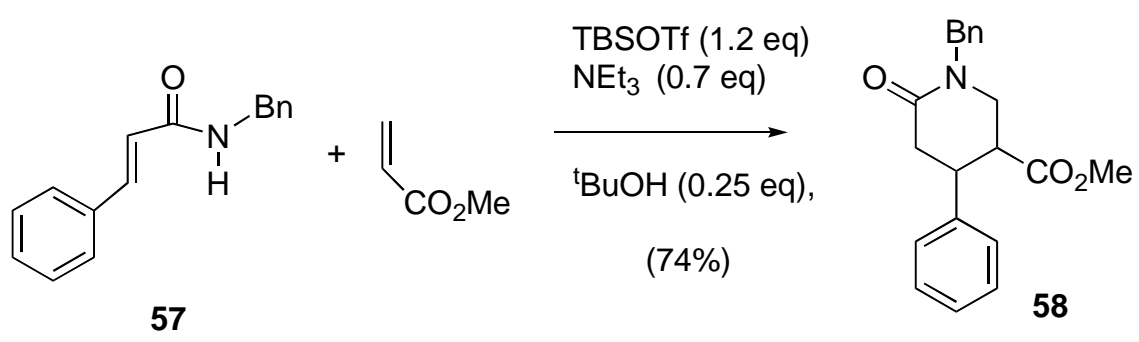

(49: $51 /$ trans : cis)

\section{Scheme 17}

Various piperidin-2-one derivatives 59 - 61 were synthesized by the combination of $\alpha, \beta$-unsaturated amides and $\alpha, \beta$-unsaturated carbonyl compounds (Scheme 18). 


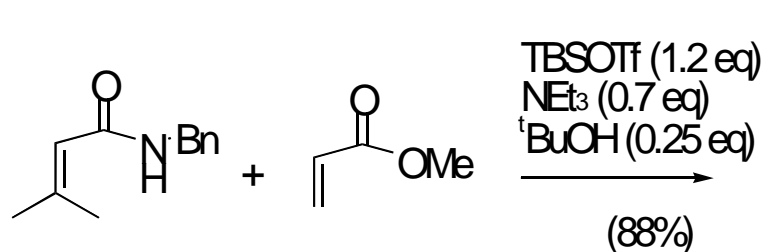<smiles>C=CC(=O)OC</smiles><smiles>O=C1C=CCCC1</smiles><smiles>CC(=O)C1CN(Cc2ccccc2)C(=O)CC1(C)C</smiles>

59<smiles>CC(=O)C1CN(Cc2ccccc2)C(=O)CC12CCCCC2</smiles>

60<smiles></smiles>

61

\section{Scheme 18}
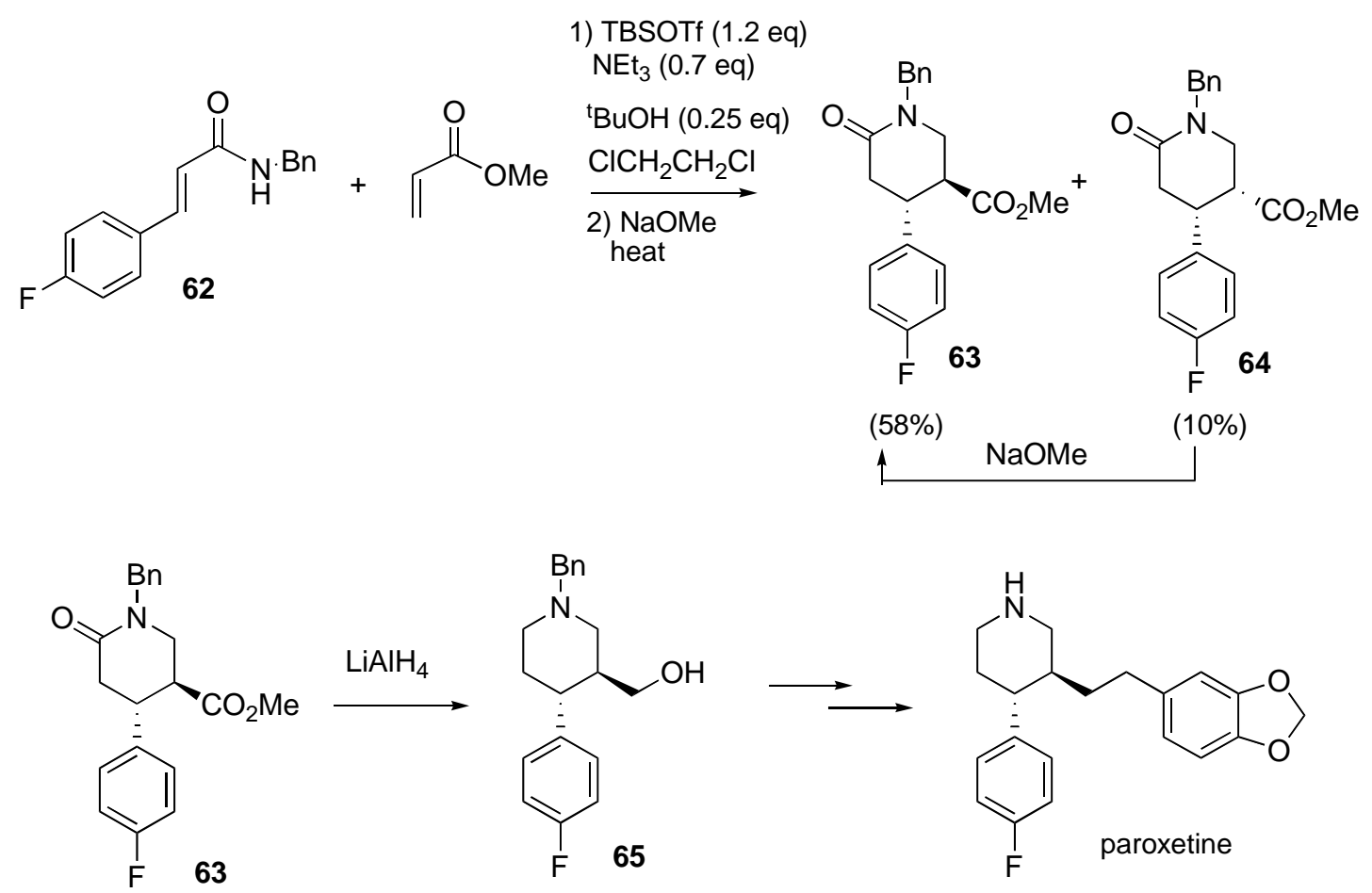<smiles>OC[C@H]1CN(Cc2ccccc2)CC[C@@H]1c1ccc(F)cc1</smiles><smiles>C=CC</smiles><smiles>CCOC(=O)OCCOc1ccc(F)cc1</smiles>

\section{Scheme 19}


The methodology was applied to the synthesis of paroxetine, a selective serotonin reuptake inhibitor (SSRI). Treatment of the mixture of the amide 62 and methyl acrylate with TBSOTf in the presence of $\mathrm{Et}_{3} \mathrm{~N}$ and $t$-BuOH provided two stereoisomers 63 and 64 . The minor cis isomer 64 could be epimerized to 63 by treatment with $\mathrm{NaOMe}$. The trans isomer 63 was reduced with $\mathrm{LiAlH}_{4}$ to afford the piperidine 65, which had been correlated with paroxetine. Thus, the important antidepressant was prepared in short steps (Scheme 19). ${ }^{26}$

We further searched the catalytic reaction conditions for the intermolecular aza double Michael reaction. The ideal reaction conditions have not yet been established, the synthesis of piperidin-2-ones from $\alpha, \beta$-unsaturated amides and $\alpha, \beta$-unsaturated carbonyl compounds was performed in two steps. Thus, a catalytic amount of $\mathrm{Pd}(\mathrm{PhCN})_{2} \mathrm{Cl}_{2}$ promoted the conjugate addition reaction of amides with enones to afford $\beta$-amideketones $\mathbf{6 6}$ and $\mathbf{6 8}$, which were then cyclized by a basic treatment to provide piperidin-2-ones 67 and $69 .{ }^{27}$
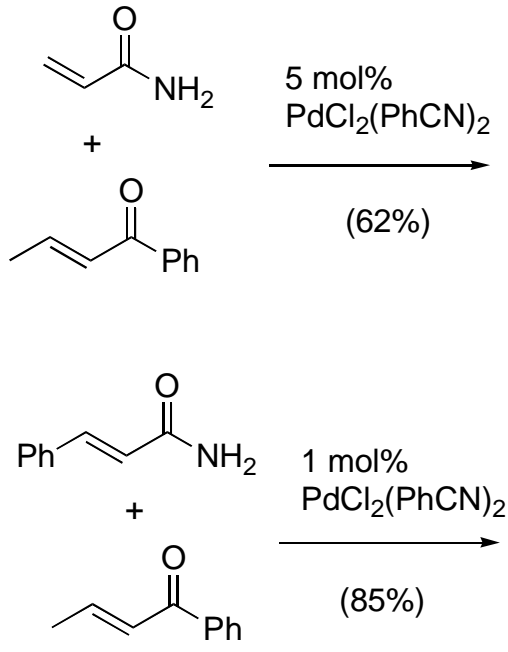

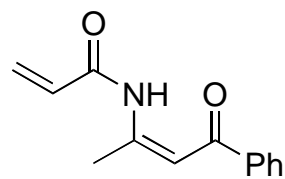

$(62 \%)$

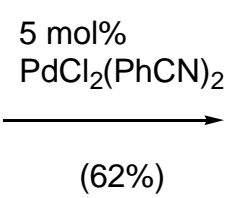

66

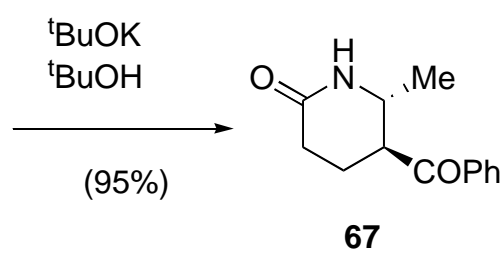

67

\section{Scheme 20}

\subsection{Michael-Aldol reaction}

Four-membered ring systems are important structural units frequently found in biologically important compounds. Among the synthetic methods available for the synthesis of cyclobutanes, $[2+2]$ cycloaddition is the most commonly used. As an extension of our study of the double Michael reaction, we envisaged the formation of polycyclic ring systems fused to a cyclobutane by the sequential Michael and aldol reactions. Namely, the cascade reactions of $\alpha$-substituted 70, $\beta$-substituted 71, and $\gamma$-substituted cyclohexanones 72 would provide tricyclic compounds 73, 74, and 75, which are the frameworks of italicene, decipiadiene, and endiandric acid $\mathrm{C}$, respectively (Scheme 21). 


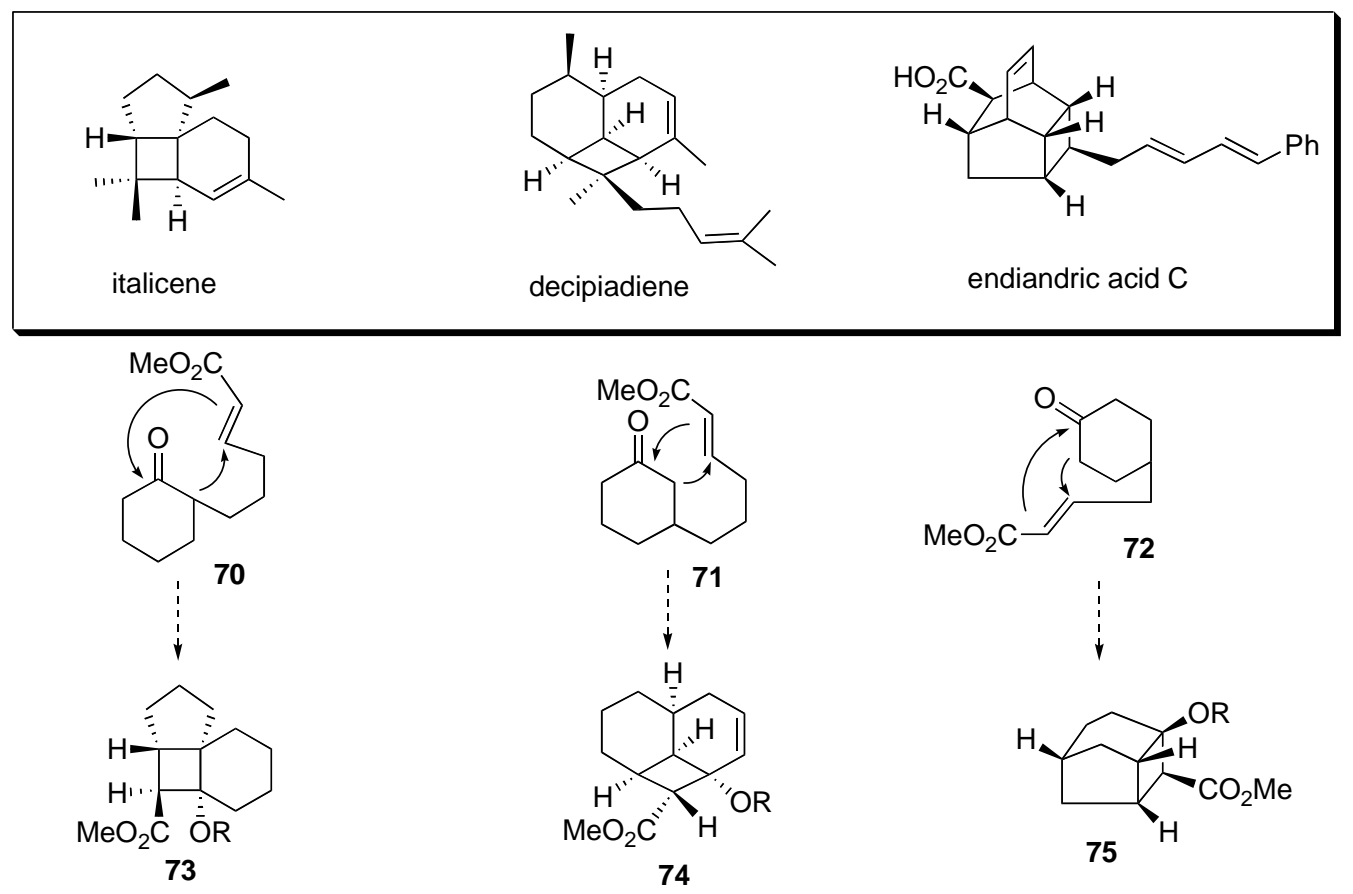

\section{Scheme 21}

The intramolecular Michael-aldol reaction could be performed under various reaction conditions, such as treatment with TBSOTf and $\mathrm{Et}_{3} \mathrm{~N}^{28}{ }^{28}$ treatment with TMSI and (TMS) ${ }_{2} \mathrm{NH},{ }^{29}$ and treatment with $\mathrm{Bu}_{2} \mathrm{BOTf}$ and $(\mathrm{TMS})_{2} \mathrm{NH}^{30}$

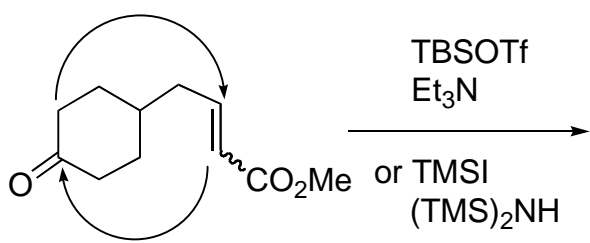

72

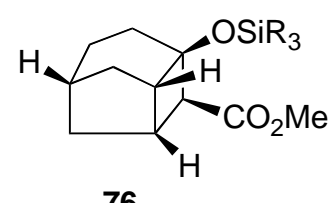

76

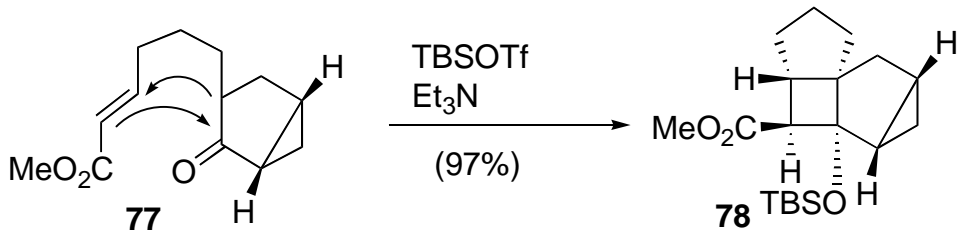<smiles>COC/C=C1/CCCC2(CCCCC2=O)CC1</smiles>

(E)-70

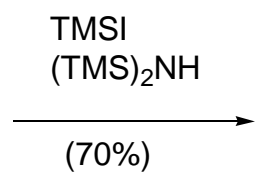

(70\%)

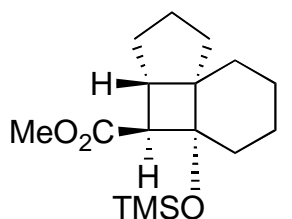

79

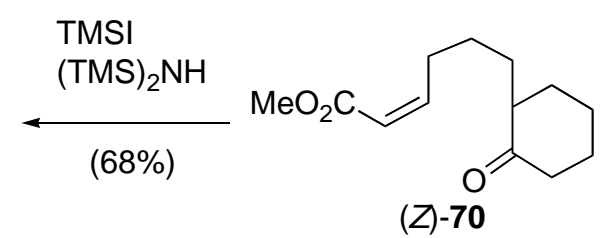

(Z)-70

\section{Scheme 22}


Thus, treatment of the symmetrical ketone 72 with TBSOTf in the presence of $\mathrm{Et}_{3} \mathrm{~N}$ or TMSI in the presence of (TMS) ${ }_{2} \mathrm{NH}$ gave 76 in a good yields (Scheme 22). Both (E)- and (Z)unsaturated esters of $\mathbf{7 2}$ produced the same compound 76. The tetracyclic compound $\mathbf{7 8}$ was obtained in a quantitative yield from 77. For the cascade reaction of $\mathbf{7 0}$ having two types of hydrogens, the thermodynamically controlled reaction conditions, TMSI-(TMS) ${ }_{2} \mathrm{NH}$, was demanded. The same product $\mathbf{7 9}$ was provided from both $(E)$ - and $(Z)-\mathbf{7 0}$. Therefore, the stepwise mechanism was clearly supported for the cascade process.

Asymmetric synthesis of the cascade reaction was further studied in the presence of chiral amines. $^{31}$

Although the intermolecular Michael-aldol reaction between ketones and $\alpha, \beta$-unsaturated carbonyl compounds has not yet been carried out, it has been made clear that four-membered carbocyclic compounds could be prepared by the reaction of the silyl enol ethers with $\alpha, \beta$ unsaturated carbonyl compounds in the presence of catalytic amount of Lewis acids (Scheme 23). ${ }^{32-34}$

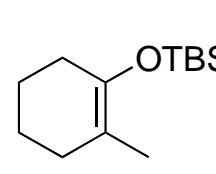

80<smiles>C=CC(=O)OC</smiles>

$\mathrm{EtAICl}$

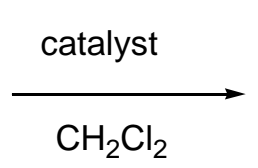

$-78^{\circ} \mathrm{C}, 1-4 \mathrm{~h}$

$\begin{array}{ll} & (20 \mathrm{~mol} \%) \\ \mathrm{Tf}_{2} \mathrm{NH} & (1.0 \mathrm{~mol} \%)\end{array}$

$\mathrm{Tf}_{2} \mathrm{NH} \quad$ (0.1 mol\%)

$\mathrm{Tf}_{2}$ NTBS (1.0 mol\%)

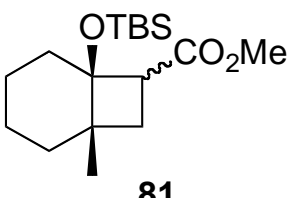

81

(trans: $\alpha$-ester; cis $\beta$-ester)

$79 \%(95: 5)$

92\% (100 : trace)

98\% (100 : trace)

$99 \%(9: 1)$

\section{Scheme 23}

The best result was obtained when the reaction was carried out in the presence of $\mathrm{Tf}_{2} \mathrm{NH}$. Use of the equivalent mole of $\mathrm{Tf}_{2} \mathrm{NH}$ gave no production of $\mathbf{8 1}$ and the bicyclic compounds $\mathbf{8 1}$ was provided in a quantitative yield by using a catalytic amount of $\mathrm{Tf}_{2} \mathrm{NTBS}$. The results indicate that the actual reagent must be $\mathrm{Tf}_{2} \mathrm{NTBS}$, which would be formed by the reaction of the silyl enol ether $\mathbf{8 0}$ with $\mathrm{Tf}_{2} \mathrm{NH}^{35}$

The above procedure is a practical method for the preparation of cyclobutane and cyclobutene derivatives. Examples of gram scale productions are shown in Scheme 24. Thus, the 
bicyclic cyclobutane $\mathbf{8 3}$ and the bicyclic cyclobutene $\mathbf{8 4}$ were synthesized in excellent yields from cycloheptanone via $\mathbf{8 2}$ in two steps under mild reaction conditions. ${ }^{34}$

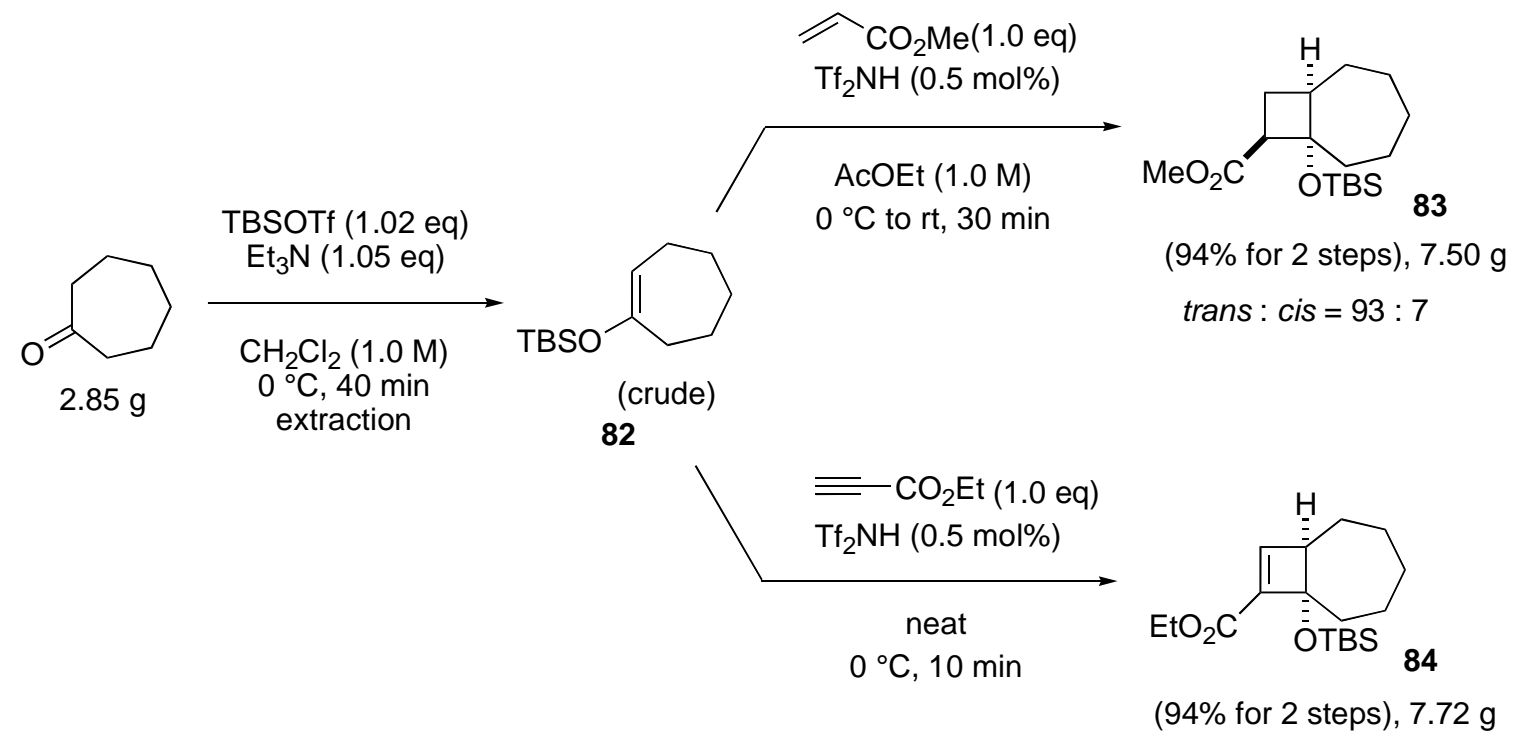

\section{Scheme 24}

Various cyclobutane derivatives 86 - 88 were prepared from 82 and 85 by the similar reactions as shown in Scheme 25.

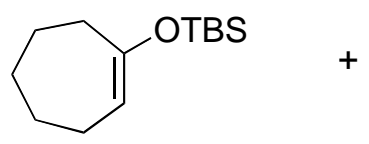

82<smiles>[SbH3]</smiles>

82<smiles>CC(C)=C([OH2+])C(C)C</smiles>

85

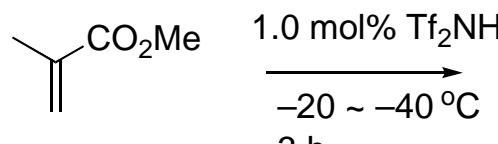

$3 \mathrm{~h}$

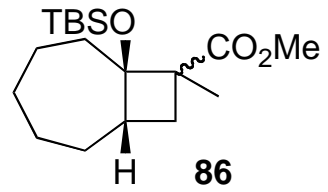

$71 \%(87: 13)$<smiles>C/C=C/C(=O)OC</smiles><smiles>NC[Po](=O)[O-]</smiles>

$3 \mathrm{~h}$

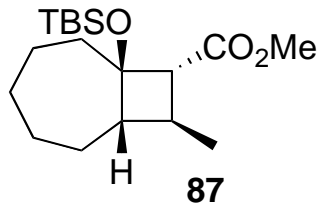

$75 \%(67: 33)$
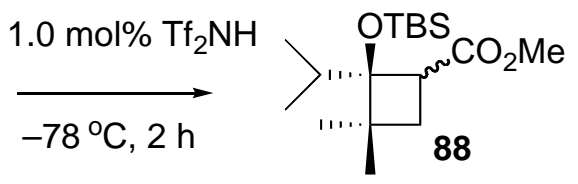

93\% (81 : 19)

\section{Scheme 25}


$\mathrm{Tf}_{2} \mathrm{NH}$ is a good catalyst for Diels-Alder reaction. Thus, bicyclic compound 91 was obtained by the cycloaddition of the enone $\mathbf{8 9}$ with diene $\mathbf{9 0}$, catalyzed by $\mathrm{Tf}_{2} \mathrm{NH}$ and then reacted with methyl acrylate in the presence of $\mathrm{Tf}_{2} \mathrm{NH}$ to afford the tricyclic compound 92 as a mixture of diastereoisomers. The tricyclic structure is a skeleton of sterpurene type sesquiterpenes (Scheme 26)

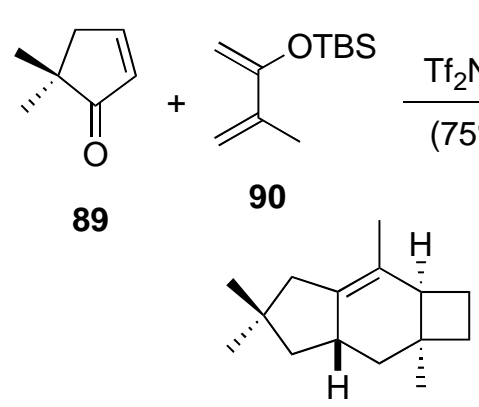

sterpurene

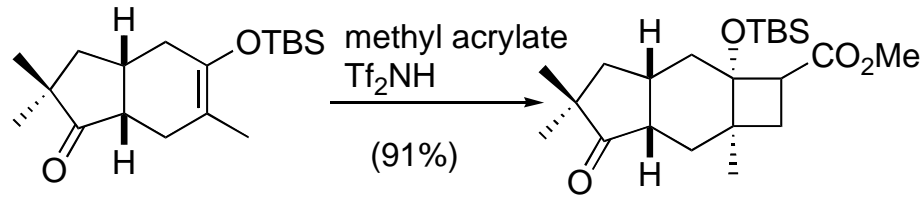

91

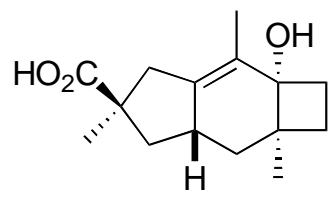

sterpuric acid

\section{Scheme 26}

On the other hand, the cycloadduct 94 from the diene 93 and the enone 89 was easily isomerized to 95 under the reaction conditions. Subsequent reaction of the resulting 95 with methyl acrylate in one pot, followed by hydrolysis of the ester group, provided the tricyclic compound 96 in 30\% overall yield as a crystalline compound (Scheme 27). The structure of the product 96 is a framework of protoilludanes (e.g. atlanticone D).

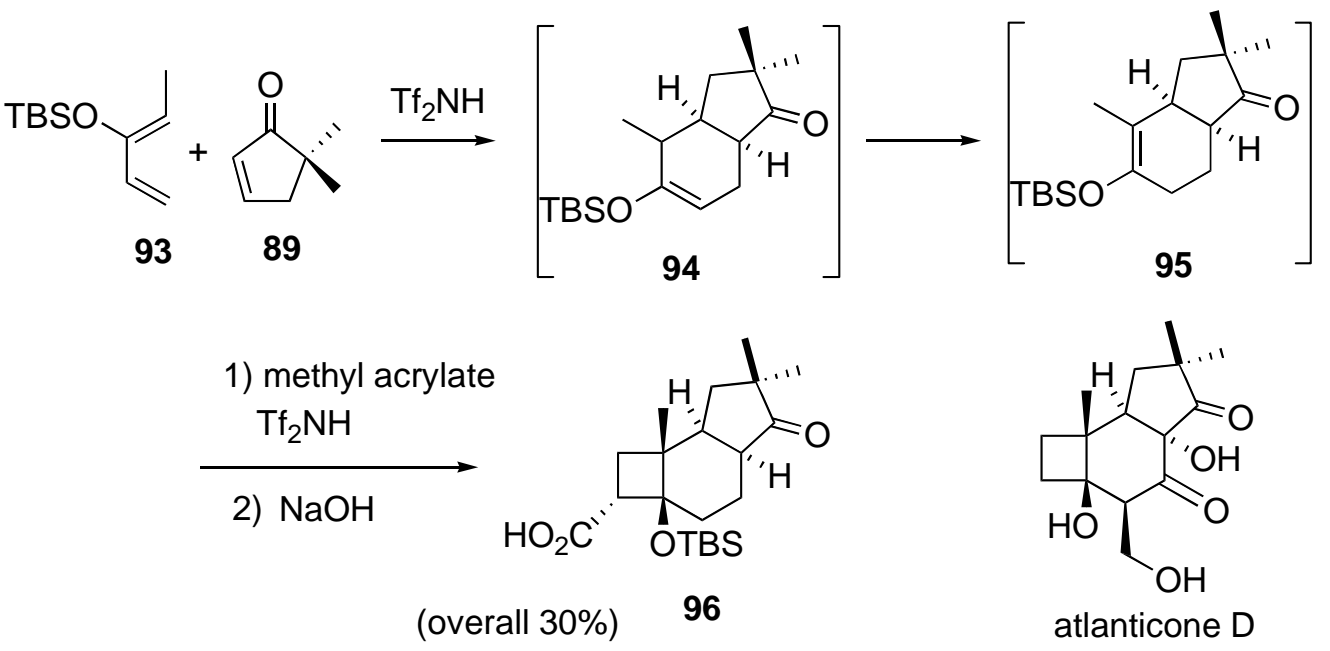

\section{Scheme 27}

On the basis of the above observations, we devised three components cascade reaction. Namely, the formation of the tricyclic compound $\mathbf{9 8}$ was achieved by the reaction of one equiv. 
of the diene $\mathbf{9 7}$ and two equiv. of methyl propiolate. The cascade reaction was conducted by three different Lewis acid as shown in Scheme 28.

Reduction of the product 98 with DIBALH provided the unexpected alcohol 99, which was then transformed into paesslerin A 100 (Scheme 29), isolated from the soft coral Alcyonium paessleri. ${ }^{36}$ The racemate of the natural product $\mathbf{1 0 0}$ was totally synthesized in $34 \%$ overall yield in 8 steps from a known compound. However, the spectral data of the synthetic compound were not consistent with the reported ones for the natural product. The structure of the synthetic compound was verified by X-ray analysis. The result clearly indicates that a revision of the structure of natural paesslerin $\mathrm{A}$ is required. ${ }^{33}$

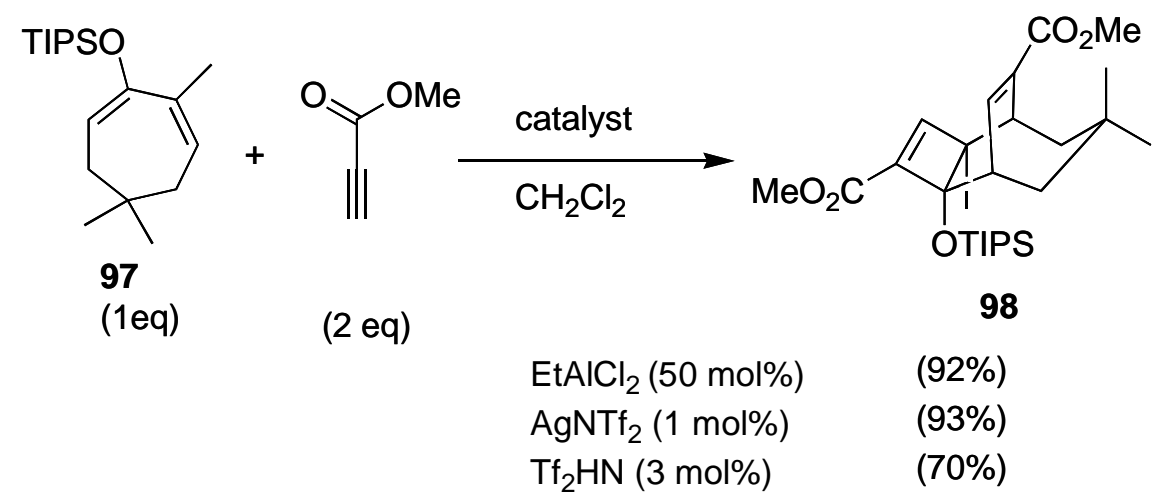

\section{Scheme 28}

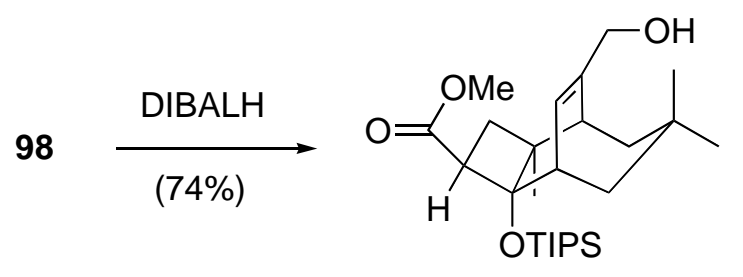

99

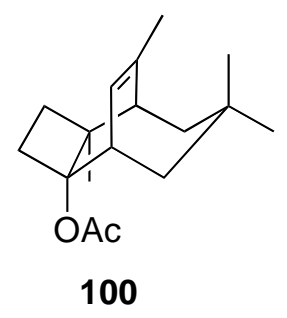

proposed paesslerin A

\section{Scheme 29}




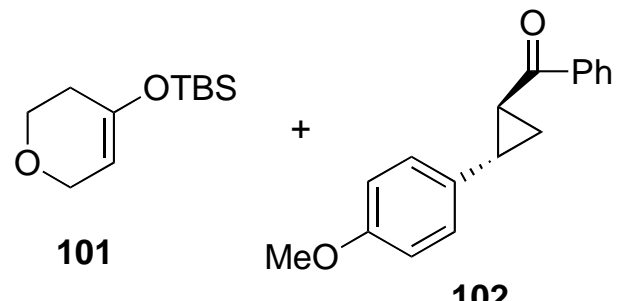

102

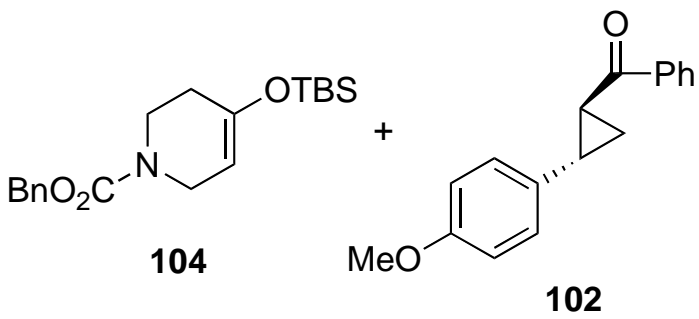

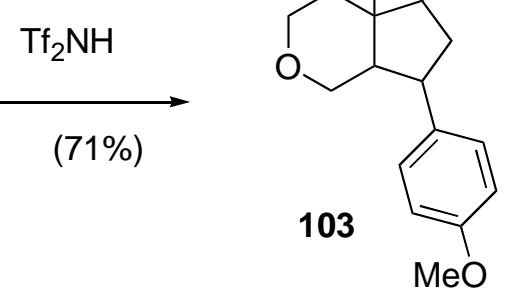

$\mathrm{Tf}_{2} \mathrm{NH}$

$(43 \%)$

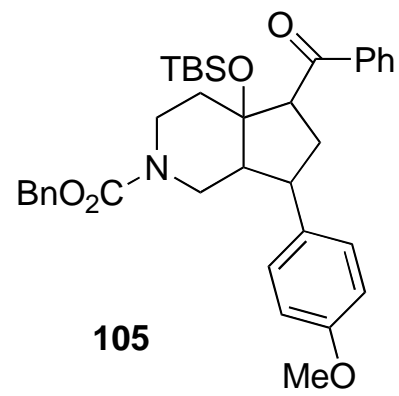

\section{Scheme 30}

It has been further demonstrated that $\mathrm{Tf}_{2} \mathrm{NH}$ is useful reagent for the Diels-Alder reaction of imines as dienophiles and the [2+2]-cycloaddition of allylsilane with $\alpha, \beta$-unsaturated esters. Additionally, the construction of the five-membered skeleton was performed in the presence of $\mathrm{Tf}_{2} \mathrm{NH}$ (Scheme 30). Thus, bicyclic compounds 103 and 105 were obtained as diastereoisomeric mixtures by treatment of the silyl enol ethers 101 and 104 with the cyclopropyl ketone 102 under the same reaction conditions as above.

The usefulness of cascade reactions for syntheses of polycyclic compounds has been demonstrated. These methodologies could be applied for the efficient preparation of various pharmacologically active compounds.

\section{Acknowledgements}

I would like to thank my coworkers, particularly my staffs, Dr. M. Toyota, Dr. K. Takasu, Dr. M. Yoshida, Dr. K. Sugimoto, and Miss A. Senbokuya, for their sincere collaboration. Names of collaborators for the present works are mentioned in references.

\section{References and Notes}

1. Posner, G. H. Chem. Rev. 1986, I, 831.

2. Jasperse, C. P.; Curran, D. P.; Fevig, T. L. Chem. Rev. 1991, 91, 1237. 
3. Tietze, L. F.; Belifuss, U. Angew. Chem. Int. Ed. 1993, 32, 131.

4. Ihara, M.; Fukumoto, K. Angew. Chem. Int. Ed. 1993, 32, 1010.

5. Bunce, R. A. Tetrahedron 1995, 48, 13103.

6. Nicolaou, K. C.; Montagnon, T.; Snyder, S. A. Chem. Comm. 2003, 551.

7. (a) Yoshida, M.; Sugimoto, K.; Ihara, M. Tetrahedron Lett. 2001, 42, 3877. (b) Yoshida, M.; Sugimoto, K.; Ihara, M. ARKIVOC 2003 (xiii), 35. (c) Yoshida, M.; Sugimoto, K.; Ihara, M. Org. Lett. 2004, 6, 1979. (d) Yoshida, M.; Komatsuzaki, Y.; Nemoto, H.; Ihara, M. Org. Biomol. Chem. 2004, 2, 3099.

8. (a) Yoshida, M.; Ihara, M. Angew. Chem. Int. Ed. 2001, 40, 616. (b) Yoshida, M.; Ihara, M. Chem. Eur. J. 2004, 10, 2886.

9. Yoshida, M.; Fujita, M.; Ishii, T.; Ihara, M. J. Am. Chem. Soc. 2003, 125, 4874.

10. Yoshida, M.; Fujita, M.; Ihara, M. Org. Lett. 2003, 5, 3325.

11. (a) Katsumata, A.; Takasu, K.; Ihara, M. Heterocycles 1999, 51, 733. (b) Takasu, K.; Kuroyanagi, J.; Katsumata, A.; Ihara, M. Tetrahedron Lett. 1999, 40, 6277. (c) Takasu, K.; Kuroyanagi, J.; Ihara, M. Org. Lett. 2000, 2, 3579. (d) Takasu, K.; Maiti, S.; Katsumata, A.; Ihara, M. Tetrahedron Lett. 2001, 42, 2157. (e) Maiti, S.; Takasu, K.; Katsumata, A.; Kuroyanagi, J.; Ihara, M. ARKIVOC 2002 (vii), 197. (f) Yokota, M.; Toyota, M.; Ihara, M. Chem. Commun. 2003, 422. (g) Toyota, M.; Ilangovan, A.; Kashiwagi, Y.; Ihara, M. Org. Lett. 2004, 6, 3629.

12. Takasu, K.; Ohsato, H.; Ihara, M. Org. Lett. 2003, 5, 3017.

13. Ihara, M.; Toyota, M.; Fukumoto, K.; Kametani, T.; Honda, T. J. Chem. Research (S) 1984, 252.

14. (a) Ihara, M.; Toyota, M.; Fukumoto, K.; Kametani, T. Tetrahedron Lett. 1984, 25, 2167. (b) Ihara, M.; Makita, K.; Tokunaga, Y.; Fukumoto, K. J. Org. Chem. 1994, 59, 6008.

15. (a) Ihara, M.; Suzuki, M.; Fukumoto, K.; Kametani, T.; Kabuto, C. J. Am. Chem. Soc. 1988, 110, 1963. (b) Ihara, M.; Suzuki, M.; Fukumoto, K.; Kabuto, C. J. Am. Chem. Soc. 1990, $112,1164$.

16. Ihara, M.; Suzuki, M.; Hirabayashi, A.; Tokunaga, Y.; Fukumoto, K. Tetrahedron Asymmetry 1995, 6, 2053.

17. Ihara, M.; Kirihara, T.; Kawaguchi, A.; Fukumoto, K.; Kametani, T. Tetrahedron Lett. 1984, 25, 4541.

18. (a) Ihara, M.; Thsruta, M.; Fukumoto, K.; Kametani, T. J. Chem. Soc., Chem. Commun. 1985, 1159. (b) Ihara, M.; Ishida, Y.; Tokunaga, Y.; Kabuto, C.; Fukumoto, K. J. Chem.. Soc., Chem.. Commun. 1995, 2085.

19. Ihara, M.; Yamada, M.; Ishida, Y.; Tokunaga, Y.; Fukumoto, K. Heterocycles 1997, 44, 531.

20. Lounasmaa, M.; Belle, D. D.; Tolvanen, A. Terahedron Lett. 1995, 36, 7141.

21. Suzuki, M.; Ihara, M. Heterocycles 2000, 52, 1083.

22. (a) Buckley, III, T. F.; Rapoport, H. J. Org. Chem. 1983, 48, 4222. (b) Nordlander, J. E.; Njorage, F. G. J. Org. Chem. 1987, 52, 1627. 
23. (a) Ihara, M.; Takino, Y. Fukumoto, K.; Kametani, T. Tetrahedron Lett. 1988, 29, 4135. (b) Ihara, M.; Takino, Y.; Tomotake, M.; Fukumoto, K. J. Chem. Soc., Perkin Trans. 1, 1990, 2287.

24. Mekouar, K.; Génisson, Y.; Leue, S.; Greene, A. E. J. Org. Chem. 2000, 65, 5212.

25. Takasu, K.; Nishida, N.; Ihara, M. Synthesis 2004, 2222.

26. (a) Takasu, K.; Nishida, N.; Ihara, M. Tetrahedron Lett. 2003, 44, 7429. (b) Takasu, K.; Nishida, N.; Ihara, M. J. Org. Chem. 2005, 70, 3957.

27. Takasu, K.; Nishida, N.; Ihara, M. Synlett 2004, 1844.

28. Ihara, M.; Ohnishi, M.; Takano, M.; Makita, K.; Taniguchi, N.; Fukumoto, K. J. Am. Chem. Soc. 1992, 114, 4408.

29. Ihara, M.; Taniguchi, T.; Makita, K.; Takano, M.; Ohnishi, M.; Taniguchi, N.; Fukumoto, K.; Kabuto, C. J. Am. Chem. Soc. 1993, 115, 8107.

30. Ihara, M.; Taniguchi, T.; Yamada, M.; Tokunaga, Y.; Fukumoto, K. Tetrahedron Lett. 1995, 36, 8071.

31. Takasu, K.; Misawa, K.; Yamada, M.; Furuta, Y.; Taniguchi, T.; Ihara, M. Chem. Commun. 2000, 1739.

32. Takasu, K.; Ueno, M.; Inanaga, K.; Ihara, M. J. Org. Chem. 2004, 69, 517.

33. Inanaga, K.; Takasu, K.; Ihara, M. J. Am. Chem. Soc. 2004, 126, 1352.

34. Inanaga, K.; Takasu, K.; Ihara, M. J. Am. Chem. Soc. 2005, 127, 3668.

35. (a) Ishikawa, K.; Hiraiwa, Y.; Yamamoto, H. Synlett 2001, 1851. (b) Mathieu, B.; Ghosez, L. Tetrahedron Lett. 1997, 38, 5497. (c) Ishii, A.; Kotera, O.; Saeki, T.; Mikami, K. Synlett 1997, 1145. (d) Cossy, J.; Lutz, F.; Alauze, V.; Meyer, C. Synlett 2000, 45. (e) Sweis, R. F.; Schramm, M. P.; Kozmin, S. A. J. Am. Chem. Soc. 2004, 126, 7442.

36. Brasco, M. F. R.; Seldes, A. M.; Palermo, J. A. Org. Lett. 2001, 3, 1415. 